\title{
Xanthohumol inhibits proliferation of laryngeal squamous cell carcinoma
}

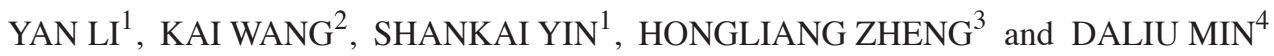 \\ ${ }^{1}$ Department of Otolaryngology, Shanghai Jiao Tong University Affiliated Sixth People's Hospital, Shanghai 200233; \\ ${ }^{2}$ Department of Otolaryngology, Zhabei Central Hospital, Shanghai 200070; \\ ${ }^{3}$ Department of Otorhinolaryngology-Head and Neck Surgery, Changhai Hospital, Second Military Medical University, \\ Shanghai 200433; ${ }^{4}$ Department of Oncology, \\ Shanghai Jiao Tong University Affiliated Sixth People's Hospital, Shanghai 200233, P.R. China
}

Received June 29, 2015; Accepted August 19, 2016

DOI: $10.3892 / \mathrm{ol} .2016 .5313$

\begin{abstract}
Xanthohumol is a flavonoid compound that exhibits antioxidant and anticancer effects, and is used to treat atherosclerosis. The aim of the present study was to investigate the effect of xanthohumol on the cell proliferation of laryngeal squamous cell carcinoma and to understand the mechanism of its action. The effects of xanthohumol on the cell viability and apoptosis rate of laryngeal squamous cell carcinoma SCC4 cells were assessed by Annexin V-fluorescein isothiocyanate/propidium iodide staining. In addition, the expression levels of pro-apoptotic proteins, caspase-3, caspase-8, caspase-9, poly ADP ribose polymerase (PARP) p53 and apoptosis-inducing factor (AIF), as well as anti-apoptotic markers, B-cell lymphoma 2 (Bcl-2) and myeloid cell leukemia 1 (Mcl-1), were analyzed by western blotting. The results revealed that treatment with $40 \mu \mathrm{M}$ xanthohumol significantly inhibited the proliferation of SCC4 cells. Furthermore, xanthohumol treatment $(40 \mu \mathrm{M})$ induced SCC4 cell apoptosis, as indicated by the significant increase in activity and expression of caspase-3, caspase-8, caspase-9, PARP, p53 and AIF. By contrast, the protein expression of Bcl-2 and Mcl-1 was significantly decreased following treatment with $40 \mu \mathrm{M}$ xanthohumol. Taken together, the results of the present study indicated that xanthohumol mediates growth suppression and apoptosis induction, which was mediated via the suppression of $\mathrm{Bcl}-2$ and $\mathrm{Mcl}-1$ and activation of PARP, p53 and AIF signaling pathways. Therefore, future studies that investigate xanthohumol as a potential therapeutic agent for laryngeal squamous cell carcinoma are required.
\end{abstract}

Correspondence to: Dr Daliu Min, Department of Oncology, Shanghai Jiao Tong University Affiliated Sixth People's Hospital, 600 Yishan Road, Shanghai 200233, P.R. China

E-mail: daliumindaliu@163.com

Key words: xanthohumol, laryngeal squamous cell carcinoma, B-cell lymphoma 2, myeloid cell leukemia 1, poly ADP ribose polymerase, p53, apoptosis-inducing factor

\section{Introduction}

Laryngeal cancer is the most common malignancy of the throat in China. At present, the incidence rate of laryngeal cancer is increasing significantly, accounting for $5.7-7.6 \%$ of all malignant tumors in the northeast areas of China (1). A number of hypotheses regarding the pathogenesis of laryngeal carcinoma exist: Smoking, alcohol consumption, air pollution and viral infection are considered the main risk factors (2). Due to the anatomical site of the larynx, patients often mistake hoarseness and other clinical symptoms of the disease as an upper respiratory tract infection or symptom of voice overuse, which results in negligence of the illness (3). Supraglottic cancer and subglottic cancer exhibit no specific symptoms at the primary stages and thus, early diagnosis is difficult, which results in the majority of cases being diagnosed at late and terminal stages (4). Due to recent advances in minimally invasive surgery, radiotherapy, chemotherapy, concurrent radiochemotherapy, biological therapy and other comprehensive treatment modalities, patient survival times have increased and patient quality of life has improved (5). However, the high rates of relapse and metastasis of laryngeal cancer in addition to chemotherapy resistance lead to poor treatment outcomes $(6,7)$. Thus, to investigate and develop novel targeted treatments for cancer, laryngeal cancer must be investigated from a novel perspective.

Effective cancer treatments aim to eradicate the majority of differentiated tumor cells, as well as tumor stem cells, which have potential to proliferate and differentiate (8). However, traditional therapies, including radiotherapy, chemotherapy and immunotherapy, kill differentiated tumor cells but not tumor stem cells, which results in the development of tumor cell resistance to treatment and subsequent relapse (9). Ideally, treatments should kill differentiated tumor cells without causing damage to other cell types, which requires the identification of specific cell markers, genes and signal transduction pathways associated with cancer that may be used as therapeutic targets to improve the efficacy of tumor treatment (10).

Xanthohumol is a flavonoid compound obtained from hops resin (11). It exhibits numerous biological properties, including anti-inflammation and anti-infection effects and has been 
demonstrated to inhibit the growth and proliferation of microorganisms (12). Recent studies investigating xanthohumol have predominantly focused on the prevention and treatment of cancer $(13,14)$. Studies have demonstrated that xanthohumol inhibits tumor cell growth of colon cancer, prostate cancer, cervical cancer, liver cancer and leukemia cells (15-17). Therefore, the aim of the present study was to investigate the effect of xanthohumol on the proliferation of human laryngeal squamous cell carcinoma. The results of the present study may indicate whether xanthohumol presents a potential drug for the treatment of human laryngeal squamous cell carcinoma and may also provide information regarding potential molecular mechanisms of the disease.

\section{Materials and methods}

Cell and reagents. The human laryngeal squamous cell carcinoma SCC4 cell line was obtained from Shanghai Jiao Tong University Affiliated Sixth People's Hospital (Shanghai, China). Dulbecco's modified Eagle's medium (DMEM), penicillin and streptomycin were purchased from Gibco (Thermo Fisher Scientific, Inc., Waltham, MA, USA). Fetal bovine serum (FBS) was obtained from Gibco (Thermo Fisher Scientific, Inc.). Xanthohumol (Fig. 1) and 3-(4,5-dimethylthiazol-2-yl)-2, 5-diphenyltetrazolium bromide (MTT) were purchased from Sigma-Aldrich (Merck Millipore, Darmstadt, Germany). Annexin V-fluorescein isothiocyanate (FITC)/propidium iodide (PI) staining kit was obtained from BestBio (Shanghai, China).

Cell culture. The SCC4 cell line was cultured in DMEM supplemented with $10 \% \mathrm{FBS}, 100 \mathrm{U} / \mathrm{ml}$ penicillin and $100 \mathrm{U} / \mathrm{ml}$ streptomycin in a humidified atmosphere with $5 \% \mathrm{CO}_{2}$ at $37^{\circ} \mathrm{C}$. The complete medium was changed every 2-3 days.

Proliferation assay. SCC4 cells (1x105/well) in the logarithmic growth phase were seeded in 96-well microplates. The medium was replaced with DMEM containing $0,10,20$, 30,40 or $50 \mu \mathrm{M}$ xanthohumol and the cells were cultured for $72 \mathrm{~h}$, after which $200 \mu \mathrm{l}$ MTT $(0.5 \mathrm{mg} / \mathrm{ml}$; Sigma-Aldrich) was added to each well. Following incubation at $4^{\circ} \mathrm{C}, 150 \mu \mathrm{l}$ DMSO was added and the absorbance was measured using a spectrophotometer (Infinite ${ }^{\circledR} 200$ PRO; Tecan, San Jose, CA, USA) at a wavelength of $540 \mathrm{~nm}$.

Annexin V-FITC/PI staining. SCC4 cells $\left(2.4 \times 10^{6} /\right.$ well) in the logarithmic growth phase were seeded in 6-well microplates. The medium was replaced with DMEM containing 20, 30 or $40 \mu \mathrm{M}$ xanthohumol and cells were cultured for $48 \mathrm{~h}$ at $4^{\circ} \mathrm{C}$. SCC4 cells $\left(1 \times 10^{6}\right)$ were harvested, washed with PBS and resuspended in binding buffer (BestBio). Next, $5 \mu 1$ Annexin V-FITC and $5 \mu \mathrm{l}$ PI were added to each well and cultured for $20 \mathrm{~min}$ at $4^{\circ} \mathrm{C}$. Apoptotic rate was determined using a flow cytometer (FACSCalibur ${ }^{\mathrm{TM}}$; BD Biosciences, San Jose, CA, USA).

Measurement of caspase-3, -8 and -9 activity. SCC4 cells $\left(2.4 \times 10^{6} /\right.$ well) in the logarithmic growth phase were seeded in 6-well microplates. The medium was replaced with DMEM containing 20, 30 or $40 \mu \mathrm{M}$ xanthohumol and cells were cultured for $48 \mathrm{~h}$ at $4^{\circ} \mathrm{C}$. SCC4 cells $\left(1 \times 10^{6}\right)$ were harvested, washed with PBS and resuspended in binding buffer. A total of $1 \mu \mathrm{l}$ fluorescent substrate [Ac-DEVD-pNA for caspase-3, Ac-IETD-pNA for caspase-8 and Ac-LEHD-pNA for caspase-9 (BestBio, Shanghai, China)] was added to each well and incubated for $1 \mathrm{~h}$ at $4^{\circ} \mathrm{C}$. Cells were then centrifuged at $500 \times \mathrm{g}$ for $10 \mathrm{~min}$ at room temperature and the supernatant was removed. The cells were resuspended in $100 \mu \mathrm{l}$ wash buffer (BestBio), and the fluorescence intensity was measured at $485 \mathrm{~nm}$ (excitation wavelength) and $535 \mathrm{~nm}$ (emission wavelength) using a spectrophotometer.

Western blot analysis. SCC4 cells $\left(2.4 \times 10^{6} /\right.$ well $)$ in the logarithmic growth phase were seeded in 6-well microplates. The medium was replaced with DMEM containing 20, 30 or $40 \mu \mathrm{M}$ xanthohumol and cells were cultured for $48 \mathrm{~h}$ at $4^{\circ} \mathrm{C}$. SCC4 cells $\left(1 \times 10^{6}\right)$ were harvested, washed with PBS, and lysed with cold RIPA buffer (BestBio) containing protease inhibitors. Protein concentrations were quantified using the bicinchonic acid assay method (BestBio). A total of $10 \mu \mathrm{g}$ protein was boiled in water prior to separation by $12 \%$ SDS-PAGE for $10 \mathrm{~min}$ then transferred onto polyvinylidene difluoride membranes at $100 \mathrm{~V}$ for $1.5 \mathrm{~h}$. Membranes were blocked with $5 \%$ skimmed milk in Tris-buffered saline with $0.1 \%$ Tween 20 for $2 \mathrm{~h}$ followed by incubation with anti-B-cell lymphoma 2 (Bcl-2; cat. no. sc-7382; 1:1,000), anti-myeloid cell leukemia 1 (Mcl-1; cat. no. sc-377487; 1:1,000), anti-poly ADP ribose polymerase (PARP; cat. no. sc-56197; 1:2,000), anti-p53 (sc-393031; 1:1,000), anti-apoptosis-inducing factor (AIF; cat. no. sc-390619; $1: 1,000)$ and anti- $\beta$-actin (cat. no. sc-47778; 1:1,000) antibodies (Santa Cruz Biotechnology Inc., Dallas, TX, USA) overnight $4^{\circ} \mathrm{C}$. The membranes were then incubated with mouse secondary antibodies (cat. no. sc-358914; 1:15,000; Santa Cruz Biotechnology, Inc.) for $2 \mathrm{~h}$ at $4^{\circ} \mathrm{C}$. The proteins were visualized using BeyoECL Star (cat. no. P0018A; Beyotime Institute of Biotechnology, Jiangsu, China) and quantified using the Molecular Imager ChemiDoc XRS+ System with Image Lab ${ }^{\mathrm{TM}}$ software (Bio-Rad Laboratories, Inc., Hercules, CA, USA).

Statistical analysis. All data are presented as the mean \pm standard error of the mean. Data was analyzed by one-way analysis of variance followed by Dunnett's t-test using SPSS version 22 statistical software (SPPS, Inc., Chicago, IL, USA). P<0.05 was considered to indicate a statistically significant difference.

\section{Results}

Xanthohumol inhibits proliferation of laryngeal squamous cell carcinoma cells. MTT assay was performed to determine the effect of xanthohumol on the proliferation of SCC4 cells following treatment with 30,40 and $50 \mu \mathrm{M}$ xanthohumol for 24,48 and $72 \mathrm{~h}$. The results revealed that xanthohumol inhibited the proliferation of SCC4 cells in a concentration- and time-dependent manner when compared with that of control group (Fig. 2). Following 24, 48 and 72 h treatment with 30, 40 and $50 \mu \mathrm{M}$ xanthohumol significantly inhibited the proliferation of SCC4 cells (Fig. 2). In addition, following treatment with $20 \mu \mathrm{M}$ xanthohumol for $72 \mathrm{~h}$ proliferation of SCC4 cells was significantly inhibited compared with the control group (Fig. 2). 
<smiles>COc1cc(O)c(CC=C(C)C)c(O)c1C(=O)/C=C/c1ccc(O)cc1</smiles>

Figure 1. Chemical structure of xanthohumol.

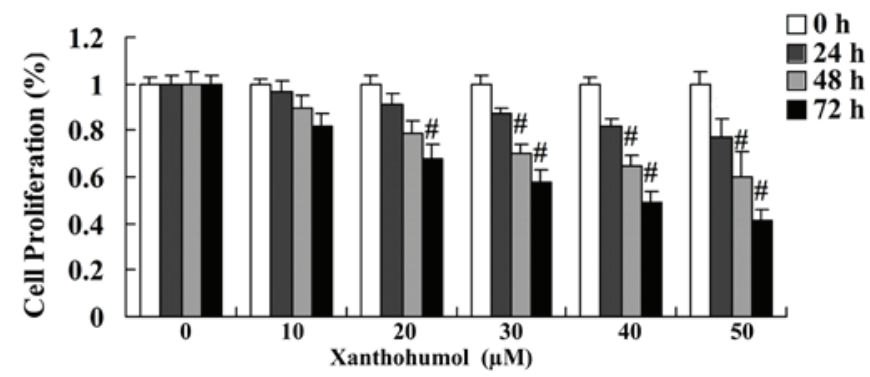

Figure 2. Treatment with $20 \mu \mathrm{M}$ xanthohumol for $72 \mathrm{~h}$, and 30,40 and $50 \mu \mathrm{M}$ for 24,48 and $72 \mathrm{~h}$ significantly inhibits the proliferation of laryngeal squamous cell carcinoma cells. ${ }^{~} \mathrm{P}<0.01$ vs. control.

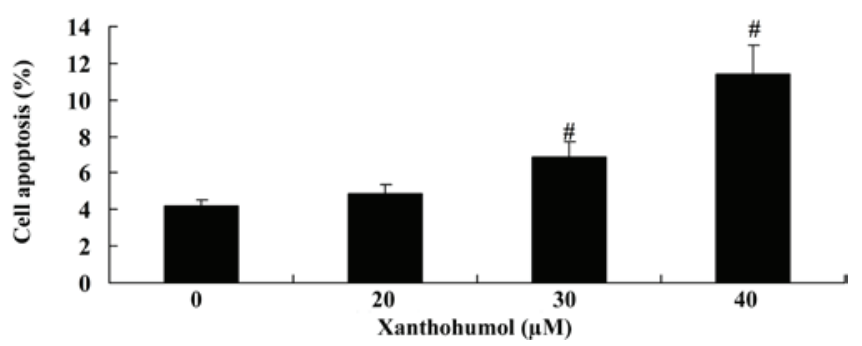

Figure 3. Xanthohumol induces cell apoptosis of laryngeal squamous cell carcinoma. ${ }^{\text {" }} \mathrm{P}<0.01$ vs. control.

Xanthohumol induces cell apoptosis of laryngeal squamous cell carcinoma cells. To evaluate the effect of xanthohumol on SCC4 cell apoptosis, flow cytometry analysis was performed. The results demonstrated that treatment with 30 and $40 \mu \mathrm{M}$ xanthohumol for $48 \mathrm{~h}$ significantly induced apoptosis of SCC4 cells compared with the control group (Fig. 3).

Xanthohumol increases caspase-3, -8 and -9 activity in laryngeal squamous cell carcinoma. To further investigate the effect of xanthohumol on caspase activity in laryngeal squamous cell carcinoma, the florescence intensities of caspase-3, -8 and -9 were measured in SCC4 cells following $48 \mathrm{~h}$ treatment with 20,30 and $40 \mu \mathrm{M}$ xanthohumol. The results revealed that caspase- $3,-8$ and -9 activity was significantly increased following treatment with 30 and $40 \mu \mathrm{M}$ xanthohumol when compared with the control group (Fig. 4).

Xanthohumol decreases Bcl-2 and Mcl-1 protein expression in laryngeal squamous cell carcinoma cells. The effect of xanthohumol on the expression of Bcl-2 and Mcl-1 proteins in laryngeal squamous cell carcinoma SCC4 cells was examined by western blot analysis. Following treatment with $40 \mu \mathrm{M}$ xanthohumol the expression of Bcl-2 (Fig. 5) and Mcl-1 (Fig. 6) proteins were significantly decreased compared with the control group.

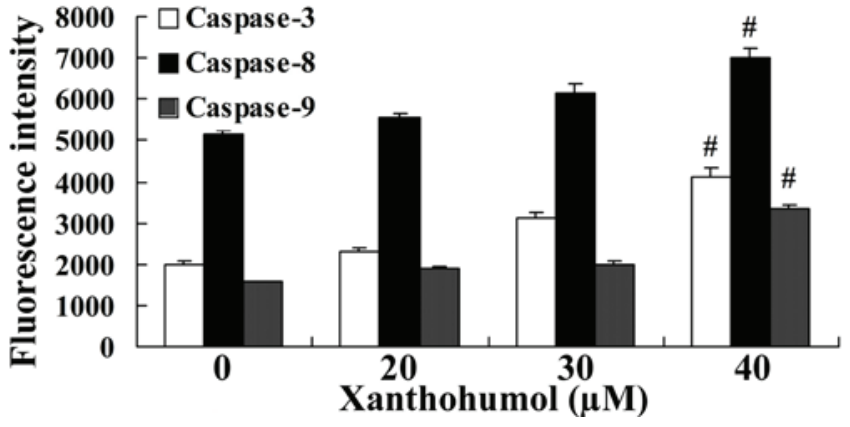

Figure 4. Xanthohumol induces caspase- $3,-8$ and -9 activity in SSC4 cells. ${ }^{\#} \mathrm{P}<0.01$ vs. control.

Xanthohumol increases PARP and p53 protein expression in laryngeal squamous cell carcinoma. The effect of xanthohumol on PARP and p53 protein expression in SSC4 cells was examined by western blot analysis. Following treatment with $40 \mu \mathrm{M}$ xanthohumol for $48 \mathrm{~h}$, the expression of PARP (Fig. 7) and p53 (Fig. 8) proteins were significantly increased compared with control group.

Xanthohumol increases AIF protein expression in laryngeal squamous cell carcinoma cells. To determine whether the AIF pathway mediates the anticancer effects of xanthohumol, AIF protein expression in $\mathrm{SCC} 4$ cells was measured using western blot analysis. Following treatment with $40 \mu \mathrm{M}$ xanthohumol for $48 \mathrm{~h}$, the expression of AIF protein was significantly increased compared with the control group (Fig. 9).

\section{Discussion}

Laryngeal squamous cell carcinoma is a common malignant tumor derived from the laryngeal epithelium, which is the third most common cause of head and neck cancer morbidity, accounting for $1-5 \%$ of all malignant tumors (2). Notably, the incidence rate of laryngeal cancer is increasing significantly among young individuals and thus, better treatments are urgently required (18). Although the treatment of laryngeal cancer has markedly improved in recent years due to advances in surgical techniques and combined chemotherapy and radiotherapy regimens, certain cases of squamous cell carcinoma of the larynx do not respond to treatment (19). Furthermore, due to the rapid development of molecular biology technology, gene therapy is gaining increasing attention and is considered to present a promising option for cancer patients (20). Therefore, the identification of specific genes that are involved in the development of laryngeal squamous cell carcinoma may lead to further studies and the clinical application of gene therapy for laryngeal cancer. Previous studies have demonstrated that xanthohumol induces apoptosis in hepatocellular carcinoma (21), human cervical cancer cells (17) and breast cancer (22). To the best of our knowledge, the present study is the first to demonstrate that xanthohumol inhibits cell proliferation and induces cell apoptosis of laryngeal squamous cell carcinoma SCC4 cells.

Cancer is a disease caused by abnormal cell proliferation, differentiation and apoptosis. It has been reported that caspases are activated during tumor cell apoptosis (23). A series of 

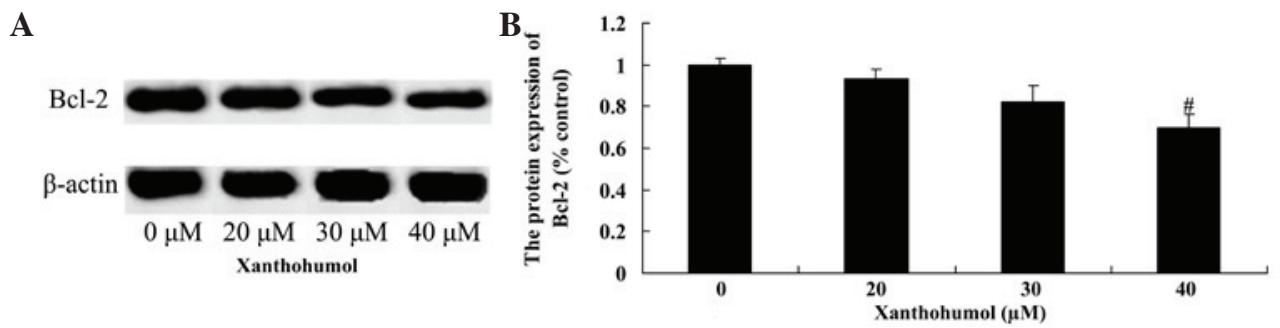

Figure 5. (A) Western blot revealing xanthohumol decreases Bcl-2 protein expression in laryngeal squamous cell carcinoma cells in a dose-dependent manner. (B) Quantification of Bcl-2 protein expression following xanthohumol treatment in laryngeal squamous cell carcinoma cells. "P<0.01 vs. control. Bcl-2, B-cell lymphoma 2 .
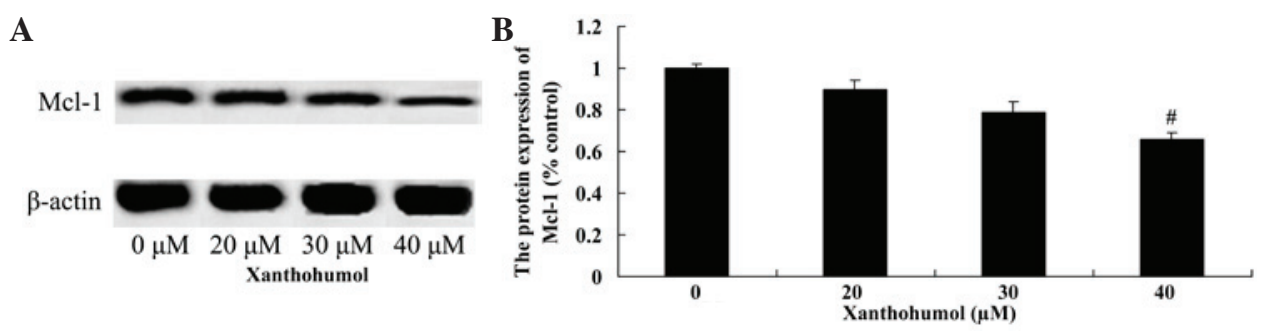

Figure 6. (A) Western blot revealing xanthohumol decreases Mcl-1 protein expression in laryngeal squamous cell carcinoma cells in a dose-dependent manner. (B) Quantification of Mcl-1 protein expression following xanthohumol treatment in laryngeal squamous cell carcinoma cells. ${ }^{\#} \mathrm{P}<0.01$ vs. control. Mcl-1, myeloid cell leukemia 1.
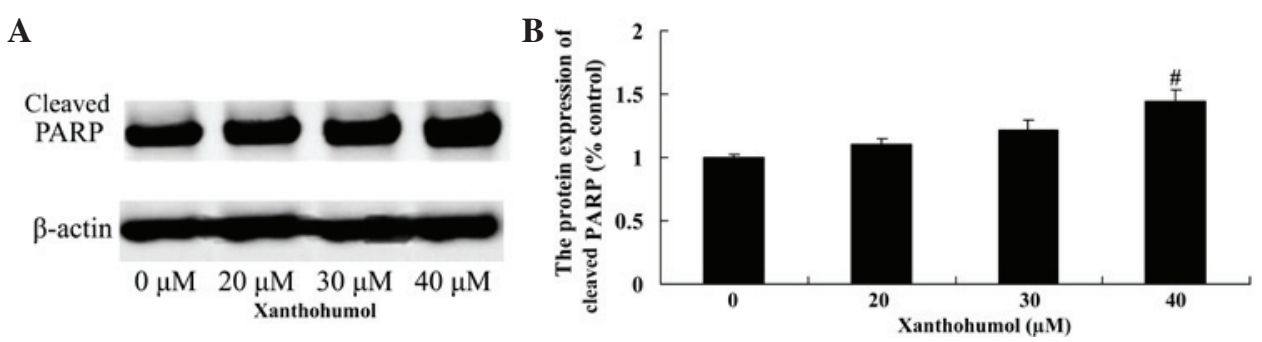

Figure 7. (A) Western blot revealing xanthohumol increases PARP protein expression in laryngeal squamous cell carcinoma cells. (B) Quantification of PARP protein expression following xanthohumol treatment in laryngeal squamous cell carcinoma cells. ${ }^{*} \mathrm{P}<0.01$ vs. control. PARP, poly ADP ribose polymerase.
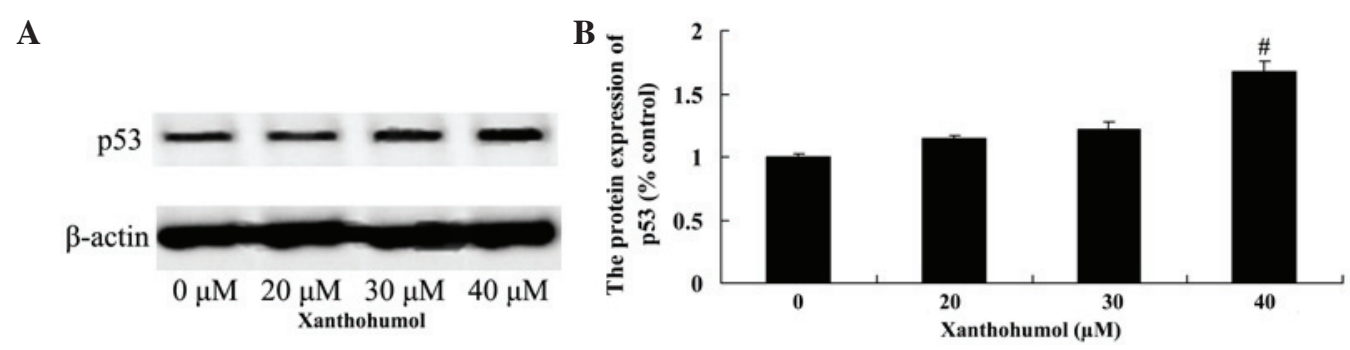

Figure 8. (A) Western blot revealing xanthohumol increases p53 protein expression in laryngeal squamous cell carcinoma cells. (B) Quantification of p53 protein expression following xanthohumol treatment in laryngeal squamous cell carcinoma cells. ${ }^{~} \mathrm{P}<0.01 \mathrm{vs}$. control.
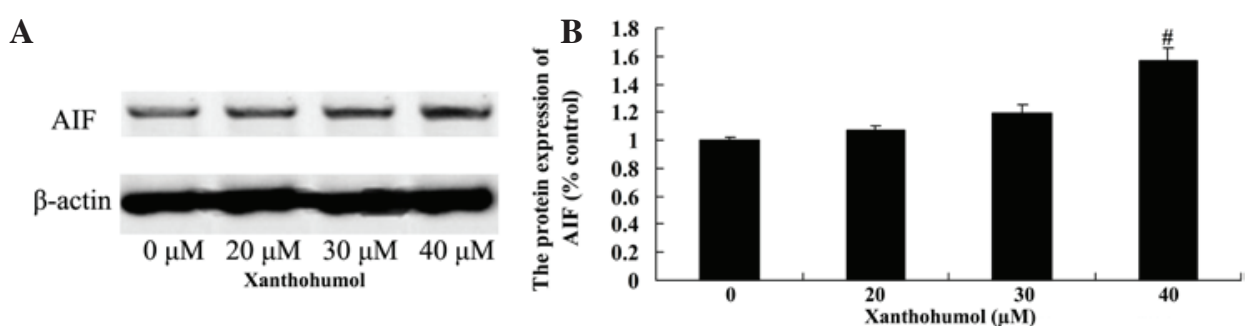

Figure 9. Western blot revealing xanthohumol increases AIF protein expression in laryngeal squamous cell carcinoma cells. (B) Quantification of AIF protein expression following xanthohumol treatment in laryngeal squamous cell carcinoma cells. " $\mathrm{P}<0.01$ vs. control. AIF, apoptosis-inducing factor. 
novel caspase-related apoptosis-inducing pathways have been identified that may be targeted to control cancer, which have practical significance for the majority of tumors and thus, may result in breakthroughs with regard to the treatment of malignant tumors (24). The activation of caspase- 9 and caspase-3 may underlie the apoptosis of fibroblasts in keloids (25). Furthermore, caspase- 8 activates caspase- 9 downstream of the apoptosis cascade to induce apoptosis (26). In the current study, xanthohumol promoted the activity of caspase-3, - 8 and -9 and suppressed Bcl-2 and Mcl-1 protein expression in laryngeal squamous cell carcinoma SCC4 cells. These results are in accordance with those reported by Pan et al (27), which demonstrated that xanthohumol induces apoptosis of human colon cancer cells via caspase-3, -8 and -9 . Furthermore, Zajc et al (15) reported that xanthohumol induces different cytotoxic and apoptotic pathways via $\mathrm{Bax} / \mathrm{Bcl}-2$ in malignant and normal astrocytes. Kunnimalaiyaan et al (28) demonstrated that xanthohumol inhibits induces apoptosis via the anti-apoptotic markers, survivin, cyclin D1 and Mcl-1, in hepatocellular carcinoma.

PARP-1 is a member of the PARP family, which initiates DNA damage repair via the modification of poly adenosine diphosphate glycosylation receptor protein. PARP-1 has been shown to trigger apoptosis signaling and activate caspase-3 to induce cell apoptosis and DNA damage $(24,29)$. Thus, we hypothesize that treatment with xanthohumol promoted PARP protein expression in laryngeal squamous cell carcinoma SCC4 cells. Lust et al (11) demonstrated that xanthohumol activates the proapoptotic pathway via PARP activation in chronic lymphocytic leukemia.

The p53 gene is recognized as the most commonly mutated tumor suppressor gene (30). Recent studies have indicated that p53 gene mutations exhibit an important function in the development of laryngeal squamous cell carcinoma $(31,32)$. The mutation rate of p53 is $>90 \%$ in certain tumors (lung, liver, colon and gastric cancer) and ranges between 34 and $93 \%$ in head and neck tumor tissues and cell lines, which is associated with early relapse of cancer (33). Xanthohumol activates PARP protein expression in laryngeal squamous cell carcinoma cells. In the present study, p53 expression increased significantly following treatment with xanthohumol. Monteghirfo et al (12) reported that xanthohumol inhibits leukemia cell invasion via p53 modulation in Bcr/Abl-transformed cells.

AIF protein, which is located in the mitochondrial intermembrane space, exhibits apoptosis-inducing activity (34). In response to apoptotic stimuli, AIF molecules are released from the mitochondria into the cytoplasm followed by translocation to the nucleus and subsequent integration with chromosomal DNA, which leads to chromosome condensation and DNA breakage into large fragments ( 50 kB) (35). AIF exhibits apoptosis-inducing activity and oxidoreductase activity, which result in interlinkage (36). Notably, AIF was the first molecule to be identified that mediates cell apoptosis directly, however, it has also been reported that caspases are involved in AIF apoptotic activity (37). The results of the present study also indicated that xanthohumol increased AIF protein expression in laryngeal squamous cell carcinoma cells. Yong and Abd Malek (17) reported that xanthohumol induces growth inhibition and apoptosis via AIF protein expression in Ca Ski human cervical cancer cells.
In conclusion, we postulate that xanthohumol mediates growth suppression and induces caspase-dependent cell death via the suppression of Bcl-2 and Mcl-1 and activation of PARP, p53 and AIF signaling pathways. Therefore, future studies that investigate xanthohumol as a potential therapeutic agent for laryngeal squamous cell carcinoma are required.

\section{References}

1. Guibert M, Lepage B, Woisard V, Rives M, Serrano E and Vergez S: Quality of life in patients treated for advanced hypopharyngeal or laryngeal cancer. Eur Ann Otorhinolaryngol Head Neck Dis 128: 218-223, 2011.

2. Tuomi L, Andréll P and Finizia C: Effects of voice rehabilitation after radiation therapy for laryngeal cancer: A randomized controlled study. Int J Radiat Oncol Biol Phys 89: 964-972, 2014.

3. Robertson SM, Yeo JC, Sabey L, Young D and MacKenzie K: Effects of tumor staging and treatment modality on functional outcome and quality of life after treatment for laryngeal cancer. Head Neck 35: 1759-1763, 2013.

4. Möhner M, Lindtner M and Otten H: Ionizing radiation and risk of laryngeal cancer among German uranium miners. Health Phys 95: 725-733, 2008.

5. Giotakis AI, Kontos CK, Manolopoulos LD, Sismanis A, Konstadoulakis MM and Scorilas A: High BAX/BCL2 mRNA ratio predicts favorable prognosis in laryngeal squamous cell carcinoma, particularly in patients with negative lymph nodes at the time of diagnosis. Clin Biochem 49: 890-896, 2016

6. Tae K, Jin BJ, Ji YB, Jeong JH, Cho SH and Lee SH: The role of laryngopharyngeal reflux as a risk factor in laryngeal cancer: A preliminary report. Clin Exp Otorhinolaryngol 4: 101-104, 2011.

7. Narwani V, Nalamada K, Lee M, Kothari P and Lakhani R: Readability and quality assessment of internet-based patient education materials related to laryngeal cancer. Head Neck 38: 601-605, 2016.

8. Xu CZ, Xie J, Jin B, Chen XW, Sun ZF, Wang BX and Dong P: Gene and microRNA expression reveals sensitivity to paclitaxel in laryngeal cancer cell line. Int J Clin Exp Pathol 6: 1351-1361, 2013.

9. Yu D, Jin C, Liu Y, Yang J, Zhao Y, Wang H, Zhao X, Cheng J, Liu $X$ and Liu C: Clinical implications of cancer stem cell-like side population cells in human laryngeal cancer. Tumour Biol 34: 3603-3610, 2013.

10. Wei X, Wang J, He J, Ma B and Chen J: Biological characteristics of CD133( $\left(^{+}\right)$cancer stem cells derived from human laryngeal carcinoma cell line. Int J Clin Exp Med 7: 2453-2462, 2014.

11. Lust S, Vanhoecke B, VAN Gele M, Boelens J, VAN Melckebeke H, Kaileh M, Vanden Berghe W, Haegeman G, Philippé J, Bracke M and Offner F: Xanthohumol activates the proapoptotic arm of the unfolded protein response in chronic lymphocytic leukemia. Anticancer Res 29: 3797-3805, 2009.

12. Monteghirfo S, Tosetti F, Ambrosini C, Stigliani S, Pozzi S, Frassoni F, Fassina G, Soverini S, Albini A and Ferrari N: Antileukemia effects of xanthohumol in Bcr/Abl-transformed cells involve nuclear factor-kappaB and p53 modulation. Mol Cancer Ther 7: 2692-2702, 2008.

13. Chen PH, Chang CK, Shih CM, Cheng $\mathrm{CH}$, Lin CW, Lee CC, Liu AJ, Ho KH and Chen KC: The miR-204-3p-targeted IGFBP2 pathway is involved in xanthohumol-induced glioma cell apoptotic death. Neuropharmacology 110: 362-375, 2016.

14. Dokduang H, Yongvanit P, Namwat N, Pairojkul C, Sangkhamanon S, Yageta MS, Murakami Y and Loilome W: Xanthohumol inhibits STAT3 activation pathway leading to growth suppression and apoptosis induction in human cholangiocarcinoma cells. Oncol Rep 35: 2065-2072, 2016.

15. Zajc I, Filipič M and Lah TT: Xanthohumol induces different cytotoxicity and apoptotic pathways in malignant and normal astrocytes. Phytother Res 26: 1709-1713, 2012.

16. Colgate EC, Miranda CL, Stevens JF, Bray TM and Ho E: Xanthohumol, a prenylflavonoid derived from hops induces apoptosis and inhibits NF-kappaB activation in prostate epithelial cells. Cancer Lett 246: 201-209, 2007.

17. Yong WK and Abd Malek SN: Xanthohumol induces growth inhibition and apoptosis in ca ski human cervical cancer cells. Evid Based Complement Alternat Med 2015: 921306, 2015. 
18. Wakisaka N, Kondo S, Endo K, Murono S and Yoshizaki T: Adjuvant chemotherapy with an oral fluoropyrimidine, S-1, following reduced RADPLAT in advanced laryngeal cancer. Ann Otol Rhinol Laryngol 121: 555-562, 2012.

19. Melinceanu L, Sarafoleanu C, Lerescu L, Tucureanu C, Caras I and Sălăgeanu A: Impact of smoking on the immunological profile of patients with laryngeal carcinoma. J Med Life 2: 211-218, 2009.

20. Wan G, Zhou L, Xie M, Chen $\mathrm{H}$ and Tian J: Characterization of side population cells from laryngeal cancer cell lines. Head Neck 32: 1302-1309, 2010.

21. Qu X, Xu C, Wang H, Xu J, Liu W, Wang Y, Jia X, Xie Z, Xu Z, $\mathrm{Ji}$ C, et al: Hippocampal glutamate level and glutamate aspartate transporter (GLAST) are up-regulated in senior rat associated with isoflurane-induced spatial learning/memory impairment. Neurochem Res 38: 59-73, 2013.

22. Yoshimaru T, Komatsu M, Tashiro E, Imoto M, Osada H Miyoshi Y, Honda J, Sasa M and Katagiri T: Xanthohumol suppresses oestrogen-signalling in breast cancer through the inhibition of BIG3-PHB2 interactions. Sci Rep 4: 7355, 2014.

23. Zhang $\mathrm{H}$, Li X, Zhang $\mathrm{Y}$ and Luan X: Luteolin induces apoptosis by activating Fas signaling pathway at the receptor level in laryngeal squamous cell line Hep-2 cells. Eur Arch Otorhinolaryngol 271: 1653-1659, 2014

24. Corbiere C, Liagre B, Terro F and Beneytout JL: Induction of antiproliferative effect by diosgenin through activation of $\mathrm{p} 53$, release of apoptosis-inducing factor (AIF) and modulation of caspase-3 activity in different human cancer cells. Cell Res 14: 188-196, 2004

25. Chen X, Deng M, Ma L, Zhou J, Xiao Y, Zhou X, Zhang C and $\mathrm{Wu} \mathrm{M}$ : Inhibitory effects of forkhead box L1 gene on osteosarcoma growth through the induction of cell cycle arrest and apoptosis. Oncol Rep 34: 265-271, 2015.

26. Akagi T, Shimizu K, Takahama S, Iwasaki T, Sakamaki K, Endo Y and Sawasaki T: Caspase-8 cleavage of the interleukin-21 (IL-21) receptor is a negative feedback regulator of IL-21 signaling. FEBS Lett 585: 1835-1840, 2011.

27. Pan L, Becker H and Gerhäuser C: Xanthohumol induces apoptosis in cultured 40-16 human colon cancer cells by activation of the death receptor- and mitochondrial pathway. Mol Nutr Food Res 49: 837-843, 2005.

28. Kunnimalaiyaan S, Sokolowski KM, Balamurugan M, Gamblin TC and Kunnimalaiyaan M: Xanthohumol inhibits Notch signaling and induces apoptosis in hepatocellular carcinoma. PLoS One 10: e0127464, 2015.
29. Kang N, Zhang JH, Qiu F, Tashiro S, Onodera S and Ikejima T: Inhibition of EGFR signaling augments oridonin-induced apoptosis in human laryngeal cancer cells via enhancing oxidative stress coincident with activation of both the intrinsic and extrinsic apoptotic pathways. Cancer Lett 294: 147-158, 2010.

30. Kropveld A, Slootweg PJ, van Mansfeld AD, Blankenstein MA and Hordijk GJ: Radioresistance and p53 status of T2 laryngeal carcinoma. Analysis by immunohistochemistry and denaturing gradient gel electrophoresis. Cancer 78: 991-997, 1996.

31. Pei SG, Wang JX, Wang XL, Zhang QJ and Zhang $\mathrm{H}$ : Correlation of survivin, p53 and Ki-67 in laryngeal cancer Hep-2 cell proliferation and invasion. Asian Pac J Trop Med 8: 636-642, 2015

32. Simsek H, Han U, Onal B and Simisek G: The expression of EGFR, cerbB2, p16, and p53 and their relationship with conventional parameters in squamous cell carcinoma of the larynx. Turk J Med Sci 44: 411-416, 2014.

33. Ogawa T, Shiga K, Tateda M, Saijo S, Suzuki T, Sasano H, Miyagi T and Kobayashi T: Protein expression of p53 and Bcl-2 has a strong correlation with radiation resistance of laryngeal squamous cell carcinoma but does not predict the radiation failure before treatment. Oncol Rep 10: 1461-1466, 2003.

34. Mendivil-Perez M, Velez-Pardo C and Jimenez-Del-Rio M: TPEN induces apoptosis independently of zinc chelator activity in a model of acute lymphoblastic leukemia and ex vivo acute leukemia cells through oxidative stress and mitochondria caspase-3 - and AIF-dependent pathways. Oxid Med Cell Longev 2012: 313275, 2012.

35. Cho SY, Lee JH, Ju MK, Jeong EM, Kim HJ, Lim J, Lee S, Cho NH, Park HH, Choi K, et al: Cystamine induces AIF-mediated apoptosis through glutathione depletion. Biochim Biophys Acta 1853: 619-631, 2015.

36. Yang R, Cui HJ, Wang H, Wang Y, Liu JH, Li Y and Lu Y: $\mathrm{N}$-stearoyltyrosine protects against glutamate-induced oxidative toxicity by an apoptosis-inducing factor (AIF)-mediated caspase-independent cell death pathway. J Pharmacol Sci 124: 169-179, 2014.

37. Hunter TB, Manimala NJ, Luddy KA, Catlin T and Antonia SJ: Paclitaxel and TRAIL synergize to kill paclitaxel-resistant small cell lung cancer cells through a caspase-independent mechanism mediated through AIF. Anticancer Res 31: 3193-3204, 2011. 